\title{
The other krill: overwintering physiology of adult Thysanoessa inermis (Euphausiacea) from the high-Arctic Kongsfjord
}

\author{
Kim Huenerlage*, Martin Graeve, Cornelia Buchholz, Friedrich Buchholz
}

Alfred Wegener Institute Helmholtz Centre for Polar and Marine Research, Am Handelshafen 12, 27570 Bremerhaven, Germany

\begin{abstract}
Polar environments like the high-Arctic Kongsfjord are characterized by pronounced seasonality leading to strong variations in primary production. Food sources are particularly scarce during winter. Herbivorous krill, such as the arcto-boreal Thysanoessa inermis, are key components in the ecosystem of Kongsfjord and strongly rely on phytoplankton as a food source. During the polar night such species must therefore be adapted to survive long periods without significant nutritional input. We investigated physiological mechanisms and the allocation of energy resources to try to explain how T. inermis manages to survive the Arctic winter. Adult specimens caught in late summer were kept under starvation conditions for $28 \mathrm{~d}$. Changes in metabolic rates (respiration and excretion) and biochemical composition (protein, lipid and fatty acid analyses) were monitored. In contrast to the Antarctic krill Euphausia superba and the subtropical E. hanseni, the arcto-boreal species did not reduce metabolism but utilized lipid reserves for survival. Assessed from total lipid stores and energy demand, the potential survival period was estimated at $63 \mathrm{~d}$ without food uptake, which is not sufficient to survive the entire winter. Results were compared to specimens that overwintered in situ and were discussed in relation to other euphausiids. In conclusion, T. inermis is well adapted to survive the Arctic winter provided that alternative food sources are available, but has a different strategy to cope with starvation than krill species from other latitudes.
\end{abstract}

KEY WORDS: Starvation $\cdot$ Respiration $\cdot$ Excretion $\cdot$ Total lipid $\cdot$ Lipid classes $\cdot$ Fatty acids $\cdot$ Proteins

\section{INTRODUCTION}

The high-Arctic Kongsfjord is located at $79^{\circ} \mathrm{N}$ on the west coast of Spitsbergen. As a high-latitude ecosystem, it is characterized by pronounced seasonal oscillations in light regime and, consequently, primary production (Hop et al. 2002). During polar winter, perpetual darkness and partial sea ice coverage lead to complete suppression of pelagic autotrophic primary production (Hop et al. 2002). As a consequence, zooplankton species at lower trophic levels relying on phytoplankton as a food source, e.g. herbivorous euphausiids, are exposed to a long period of food deprivation.

\footnotetext{
*Corresponding author: kim.huenerlage@awi.de
}

Euphausiids (krill) are pivotal components of pelagic macrozooplankton communities throughout the world's oceans, including Arctic and sub-Arctic marine ecosystems. They appear in substantial numbers and occupy a central trophic position by directly linking primary production to higher trophic levels with high efficiency (Falk-Petersen et al. 2000, Dalpadado \& Mowbray 2013). The krill community of the Kongsfjord is dominated by the arcto-boreal Thysanoessa inermis (Buchholz et al. 2010), an essentially herbivorous species. Due to its remarkable high lipid content, mainly consisting of energy-rich wax esters (Sargent \& Falk-Petersen 1981, Saether et al. 1986, Huenerlage et al. 2014), T. inermis plays a significant

() The authors 2015. Open Access under Creative Commons by Attribution Licence. Use, distribution and reproduction are unrestricted. Authors and original publication must be credited. 
role in energy transfer within the marine food web. It is believed to be the main nutritional resource for many adult fish, seabirds and marine mammals regularly occurring in the Kongsfjord (e.g. Dalpadado \& Mowbray 2013, Lydersen 2014). Particularly during the winter, when calanoid copepods are rare in the water column due to diapause (e.g. Auel et al. 2003), $T$. inermis provide a sustained and stable source of energy-rich nutrition for planktivorous predators.

In Arctic waters, T. inermis has a life span of 3 to 4 yr (Dalpadado \& Skjoldal 1996). It must therefore have some specific adaptation to survive long periods of food absence during several Arctic winters. Given its high lipid content, the species may contain enough energy to survive the winter without (or with only a minimum of) food uptake (Falk-Petersen et al. 2000). Fatty acid analyses indicated a temporary dietary shift to benthic detrivorous and carnivorous feeding (Sargent \& Falk-Petersen 1981). In addition, $T$. inermis could reduce its energetic costs by body shrinkage, sexual regression (Dalpadado \& Ikeda 1989) and significant reduction of metabolic rates (e.g. Auerswald et al. 2009, Huenerlage \& Buchholz 2013).

Nevertheless, to date it is not yet known from direct experiments how this key species reacts metabolically to food absence, i.e. how $T$. inermis regulates its overall metabolism in detail to meet energetic requirements during the Arctic polar night.

Starvation experiments are approaches suited to uncover the metabolic survival strategy of a species during times of food scarcity, i.e. over winter (Atkinson et al. 2002, Kreibich et al. 2008). In krill, such experiments were used to reveal the overwintering strategy of Antarctic Euphausia superba (Ikeda \& Dixon 1982, Auerswald et al. 2009) or to show the survival strategy of adult E. hanseni from the Benguela upwelling between upwelling pulses (Huenerlage \& Buchholz 2013).

Accordingly, in the present study, we performed a starvation experiment aimed at elucidating the specific survival patterns utilized by the arcto-boreal $T$. inermis during 28 consecutive days of food absence. To best predict the starvation-induced metabolic changes, we investigated a variety of physiological parameters throughout the experiment: metabolic rates (respiration and ammonium excretion), lipid dynamics (total lipid, lipid class and fatty acid composition), elemental and biochemical composition (carbon, nitrogen and protein content), as well as general life parameters (e.g. sex, size, weight, mortality, moulting). Furthermore, we calculated the maximum potential duration of survival under starvation conditions based on energy demand and total lipid storage.
Results from the starvation experiment were compared to those from the same set of analyses conducted on $T$. inermis sampled in the early spring of the following year, i.e. as a reference to individuals that overwintered in the Kongsfjord in situ. Our results on the adaptational starvation capacity of $T$. inermis were compared to euphausiid species from other regions, particularly to the Antarctic E. superba and the subtropical upwelling species E. hanseni.

\section{MATERIALS AND METHODS}

\section{Sample collection}

Adult Thysanoessa inermis were sampled during daytime in the high-Arctic Kongsfjord, West Spitsbergen on 7 August $2012\left(78.97^{\circ} \mathrm{N}, 12.28^{\circ} \mathrm{E}\right)$ and on 6 April $2013\left(78.96^{\circ} \mathrm{N}, 11.94^{\circ} \mathrm{E}\right)$ on-board the Kings Bay AS workboat MS 'Teisten' with a $1 \mathrm{~m}^{2}$ Tucker trawl (1000 $\mu \mathrm{m}$ mesh size and soft cod-end bucket) towed at 2 knots. The hauls were taken from $90 \mathrm{~m}$ (August 2012) and $300 \mathrm{~m}$ depth (April 2013; depths of maximum abundance at the stations sampled; authors' pers. obs.). Shortly after the catch, the specimens were transferred to aerated aquaria containing filtered seawater and acclimated for $12 \mathrm{~h}$ at $4^{\circ} \mathrm{C}$ in dim light before being used for respiration and excretion measurements and in the starvation experiment.

All specimens sampled were scored for individual visible life parameters, namely: sex, size (from the front of the eyes to the tip of the telson to the nearest millimetre), fresh weight (FW), stomach fullness, hepatopancreas colour, lipid stage (i.e. size of the 'lipid body' located in the species' cephalothorax [Buchholz et al. 2010]), sexual development and moult stage (Buchholz 1982). Afterwards, the specimens were rinsed in distilled water, deep-frozen in liquid nitrogen and stored at $-80^{\circ} \mathrm{C}$ for later analyses at the Alfred Wegener Institute, Bremerhaven (Germany).

\section{Starvation experiments}

A total of 104 adult T. inermis were chosen for the starvation experiment. To follow each specimen's condition over the time of starvation, i.e. as an estimation of start conditions, specific life parameters (stomach fullness, hepatopancreas colour and lipid stage [Buchholz et al. 2010]) were determined before the specimens were individually placed in 11 Kautex bottles filled with filtered $(0.2 \mu \mathrm{m})$ seawater of $4^{\circ} \mathrm{C}$ 
(provided by Kings Bay Marine Laboratory, NyÅlesund, Spitsbergen). The bottles were kept in a water bath in dim light. The experiment lasted $4 \mathrm{wk}$ $(28 \mathrm{~d})$. The specimens were checked twice daily for mortality and moulting, and exuviae were immediately removed from the bottles. The intermoult period (IMP) was calculated according to Tarling et al. (2006). Only the moults occurring within the first $3 \mathrm{~d}$ were considered in order to reduce laboratory artefacts (Buchholz 2003).

Water exchange and random subsampling were performed every 5th day and on the last (28th) day of starvation (T28). Subsamples were used for immediate metabolic rate measurements (respiration and excretion) and for later analyses of biochemical composition (lipid compositions, protein content and carbon to nitrogen mass ratio). A sample of up to $8 \mathrm{~T}$. inermis specimens served as a control group (T0) for metabolic rates $(\mathrm{n}=8)$, lipid composition $(\mathrm{n}=4$, only females) and overall specimen condition (visible life parameters; $\mathrm{n}=8$ ) at the start of the experiment.

\section{Metabolic rate measurements}

The respiration and excretion measurements were carried out on female and male $T$. inermis randomly sampled at the beginning of the starvation experiment (T0) and on the 5th, 10th, 15th, 20th and 25th day of starvation ( $\mathrm{T} 5$ to $\mathrm{T} 25)$, as well as after overwintering ( $\mathrm{OW}$; specimens sampled in April 2013). The specimens were individually incubated in specially designed horizontal tubular chambers (Perspex; total volume of $20 \mathrm{ml}$ [Huenerlage \& Buchholz 2013]). The chambers were filled with filtered seawater at $4^{\circ} \mathrm{C}$ and stored in a water bath in the dark in a temperature-controlled refrigerator. Two chambers were prepared without an animal to serve as controls. The oxygen consumption (mg $\mathrm{O}_{2} \mathrm{l}^{-1}$ ) was monitored every $30 \mathrm{~s}$ by optode respirometry with a 10-channel optode respirometer (PreSens Precision Sensing Oxy-10 Mini). The measurements lasted about $3 \mathrm{~h}$ and were stopped when the oxygen concentration inside the test-chambers reached $60 \%$ of the initial concentration.

Ammonium $\left(\mathrm{NH}_{4}-\mathrm{N}\right)$ excretion was determined in water samples $(500 \mu l)$ taken from each chamber (including controls) at the end of each respiration measurement. The samples were frozen and stored at $-80^{\circ} \mathrm{C}$ for later analyses. They were analysed photometrically using a microplate reader $(630 \mathrm{~nm}$; Multiskan ${ }^{\mathrm{TM}}$ FC Microplate Photometer, Thermo Scientific) following the phenol-hypochlorite method of Solorzano (1969).
Both the respiration and the ammonium excretion rates were expressed in $\mu \mathrm{mol} \mathrm{h} \mathrm{h}^{-1} \mathrm{gFW}^{-1}$.

The oxygen $(\mathrm{O})$ to nitrogen $(\mathrm{N})$ ratio derived from the metabolic rate measurements was used as an indicator of the substrate metabolized: O:N $<24$ for protein and O:N > 24 for lipid (Mayzaud \& Conover 1988).

\section{Biochemical composition}

To avoid sex-specific influences only female $T$. inermis (sampled on T5 and T25) were analysed for biochemical composition. Whole animals were lyophilized for $24 \mathrm{~h}$, their dry weights were determined, and, subsequently, the animals were individually ground to powder using a glass tissue grinder. Subsamples of the powder were used for protein and organic $\mathrm{C}$ and $\mathrm{N}$ analyses.

Total protein was determined using the Bio-Rad $D C$ Protein Assay, with bovine serum albumin as the standard. Krill powder (2 to $3 \mathrm{mg}$ ) was homogenated in $1 \mathrm{~mL} \mathrm{NaOH}(1 \mathrm{M})$ by using an ultrasound sonotrode at about $35 \%$ of maximum power (BRANSON SONIFIER ${ }^{\circledR}$ cell disruptor B15) and incubated for $2 \mathrm{~h}$ at $60^{\circ} \mathrm{C}$. Afterwards, the homogenate was centrifuged at room temperature for $10 \mathrm{~min}$ at $10000 \times \mathrm{g}$. The supernatant was subsampled $(\mathrm{n}=3)$ for photometrical determination of protein using a microplate reader $\left(750 \mathrm{~nm}\right.$; Multiskan ${ }^{\mathrm{TM}}$ FC Microplate Photometer, Thermo Scientific). The total content was expressed as a percent of dry weight.

The analyses of carbon and nitrogen content used the same amounts of krill powder and were performed in an elemental analyser (Euro EA CHNS- O elemental analyser, HEKAtech $\mathrm{GmbH}$ ), with acetanilide as the standard.

\section{Lipid composition analyses}

To avoid sex-specific influences only female specimens (sampled at T0, T15, T28 and OW), were analysed for lipid composition. Lipids were extracted from lyophilized whole specimens $(24 \mathrm{~h})$ of known dry weight. The total content was determined gravimetrically (Hagen 2000) and expressed as a percent of dry weight. The extractions were performed in the laboratories of the Department of Marine Zoology, University of Bremen (BreMarE), Germany.

The lipid classes were analysed from aliquots of the total lipid extracts. The separation and identification utilized a silica column (Chromolith ${ }^{\circledR}$ Performance-Si 
$100 \times 4.6 \mathrm{~mm}$ i.d.) using high-performance liquid chromatography (LaChromElite HPLC system; VWR), with a SEDEX 40 evaporative light-scattering detector (Graeve \& Janssen 2009). A commercially available standard representing a single lipid class was used for identification. Lipid classes were quantified as a percent of total lipid.

Fatty acid and fatty alcohol compositions were identified according to Kattner \& Fricke (1986). Aliquots of the total lipid extracts were hydrolysed in methanol containing $3 \%$ concentrated sulphuric acid under nitrogen atmosphere and transesterificated for $4 \mathrm{~h}$ at $80^{\circ} \mathrm{C}$. Subsequent analyses were done by gas liquid chromatography (HP 6890N GC) on a wallcoated open tubular column $(30 \times 0.25 \mathrm{~mm}$ i.d.; film thickness: $0.25 \mu \mathrm{m}$; liquid phase: DB-FFAP) using temperature programming. Standard mixtures served to identify the fatty acid methyl esters and the fatty alcohol derivates. Detailed fatty acid and alcohol compositions were expressed as a percent of total fatty acids and a percent of total fatty alcohols, respectively.

\section{Calculation of potential maximum starvation}

The potential maximum starvation period of $T$. inermis was estimated from the available mean lipid deposit and the mean daily energy requirements found in unstarved specimens at the start of the starvation experiment. From this, the theoretical loss in lipid over the time of the experiment was estimated. For the calculation of the energy deposit of an average specimen, the mean available lipid deposit (mg) was converted to energy units (J) assuming a caloric equivalent of $42.69 \mathrm{~J} \mathrm{mg}^{-1}$ for wax ester-dominated lipids (Auel et al. 2003). The average daily energy requirement was calculated from the specimens' mean respiration rate assuming

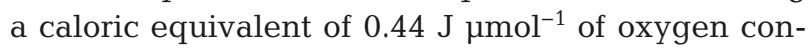
sumed for lipid (Ikeda et al. 2000).

\section{Statistics}

The statistical analyses were performed using the GraphPad Prism 5 software (GraphPad Software, Inc.). A 1-way ANOVA with a post hoc Dunnett test was used to detect significant differences between starved (T5 to T28) and non-starved (T0) krill. Differences between the field-sampled specimens after winter (April 2013, OW) and at the end of summer (August 2012, T0) were analysed with an unpaired t-test. The same test was used to compare OW specimens to $T$. inermis after $28 \mathrm{~d}$ of starvation (T28). The significance level was set at $\mathrm{p}<0.05$. All results are given as means \pm standard deviations unless specified otherwise.

\section{RESULTS}

A total of 50 females, 47 males and 7 neuters were used in the starvation experiment. All females and males were sexually inactive, i.e. neither ovaries nor spermatophores were visible. In the neuters the high degree of sexual regression did not allow for sex determination. All following parameters in this subsection were measured for both male and female specimens.

At T0, the majority $(80 \%)$ of the specimens had empty stomachs and colourless hepatopancreases $(87 \%)$. The mean lipid stage at the start was $4.2 \pm$ 0.5 , i.e. a high lipid store. The specimens were on average $24.7 \pm 1.8 \mathrm{~mm}$ long and had a FW of $119.1 \pm$ $25.8 \mathrm{mg}$. The survival rate during the $28 \mathrm{~d}$ was $80 \%$. The in situ intermoult period of the specimens sampled in August 2012 was 11 d. Continuous investigations on the individuals' moult stages showed that the specimens remained actively moulting throughout the experiment, maintaining the initial intermoult period.

The OW specimens sampled in April 2013 were still sexually inactive (sexual development stage $=0$ ). All specimens had empty stomachs and colourless hepatopancreases. The mean lipid stage was $3.6 \pm$ 0.7 and was significantly lower compared to the specimens from August 2012 ( $t$-test: $\mathrm{p}=0.0073, t=$ 2.7 , df = 109). Additionally, although of about the same body length $(23.5 \pm 1.7 \mathrm{~mm})$, the specimens from April 2013 had a lower FW of $91.0 \pm 26.5 \mathrm{mg}$ ( $t$-test: $\mathrm{p}=0.0155, t=2.6, \mathrm{df}=26$ ).

\section{Metabolic rates}

Respiration and excretion rates were the same in both female and male Thysanoessa inermis specimens (tested for each sampling period; unpaired $t$-test). Accordingly, the data were pooled for comparison of the sampling periods.

The rates did not change over time of starvation (T0 to T28) and did not differ from OW specimens. Accordingly, the atomic oxygen to nitrogen ratio (O:N) did not differ among all the specimens sampled (Fig. 1). At $4^{\circ} \mathrm{C}$ experimental temperature, mean 
respiration rates ranged on average from $\sim 6 \mu \mathrm{mol}$ $\mathrm{O}_{2} \mathrm{~h}^{-1} \mathrm{gFW}^{-1}$ (at days of starvation T0 to T10 and OW; Fig. 1) to $\sim 7 \mu \mathrm{mol} \mathrm{O}_{2} \mathrm{~h}^{-1} \mathrm{gFW}^{-1}$ (at days of starvation T15 to T25). Excretion rates ranged on average from $\sim 0.5 \mu \mathrm{mol} \mathrm{NH} \mathrm{NH} \mathrm{h}_{4}^{-1} \mathrm{~g} \mathrm{FW}^{-1}$ (at days of starvation T5 to T15 and OW) to $\sim 0.6 \mu \mathrm{mol} \mathrm{NH}_{4}-\mathrm{N} \mathrm{h}^{-1}$ $\mathrm{gFW}^{-1}$ (at days of starvation T0, T20 and T25). Mean $\mathrm{O}: \mathrm{N}$ ratios were $>24$ in all treatments, suggesting preferential catabolism of lipids (Fig. 1).

\section{Elemental and biochemical composition}

On the last day of the experiment, the specimens had a significantly lower dry weight $(20.5 \pm 1.3 \mathrm{mg})$ compared to specimens from the beginning $(30.0 \pm 1.6 \mathrm{mg} ; 1$ way ANOVA: $p<0.0001, F_{4,17}=11.7$; post hoc Dunnett test: T0 vs. T28, p $<0.0001$; Table 1). However, total body protein $(\sim 35 \%)$ and the C:N ratio ( $\sim 6)$ remained stable over the total starvation period (Table 1). In contrast, total lipid decreased considerably from $\sim 42 \%$ at the beginning (T0) to $\sim 28 \%$ at the end of the experiment $(\mathrm{T} 28 ; 1$ way ANOVA: $p=0.0124, F_{2,8}=8.0 ;$ post hoc Dunnett test: T0 vs. T28, p $<0.05$; Table 1). Simultaneously, the size of the lipid body decreased visibly (1-way ANOVA: $\mathrm{p}=0.0136$, $F_{6,76}=2.9$; Fig. 2).

Mean relative lipid class composition changed during the experiment (Fig. 3). The relative amounts of both the triacylglycerols (from $\sim 17 \%$ at T0 to $14 \%$ at T28) and wax esters (from $\sim 50 \%$ at T0 to $44 \%$ at T28) decreased, whereas those of polar lipids (phosphatidylcholine: from $\sim 29 \%$ at T0 to $\sim 35 \%$ at T28; phosphatidylethanolamine: from $\sim 3 \%$ at T0 to $5 \%$ at T28) increased. Due to high variance, the differences were not significant. The increase in sterols (from $\sim 1 \%$ at $\mathrm{T} 0$ to $3 \%$ at T28), however, was statistically different (1-way ANOVA: $p=0.0305, F_{2,8}=5.6$; post hoc Dunnett test: T0 vs. T28, p < 0.05).

In all specimens sampled, the total lipids consisted of $\sim 17 \%$ fatty alcohols and $\sim 83 \%$ fatty acids; 5 fatty alcohols and 13 fatty acids were detected, each accounting for $>1 \%$ of the total composition (Table 2). The fatty alcohol composition was dominated by 14:0, $16: 0$ and 16:1(n-7) ( 25, 60 and $\sim 16 \%$ of total fatty alcohols, respectively). The relative amounts of these alcohols did not change during starvation (Table 2). Both 20:1 and 22:1 fatty alcohols were present in traces in $T$. inermis sampled at the beginning of the experiment but were absent at the end of the starvation experiment (T28).

Among the fatty acids, 16:0, 16:1(n-7), 18:1(n-9), 18:1(n-7) and 20:5(n-3) were detected in the highest amounts in all specimens. Long-chain 20:1(n-9) and 22:1(n-11) fatty acids were only found in traces $(<1 \%)$. Except for the increase in the amount of the fatty acid 22:6(n-3) (1-way ANOVA: $\mathrm{p}=0.0466, F_{2,8}=$ 4.6; post hoc Dunnett test: T0 vs. T28, $\mathrm{p}<0.05$; Table 2 ),

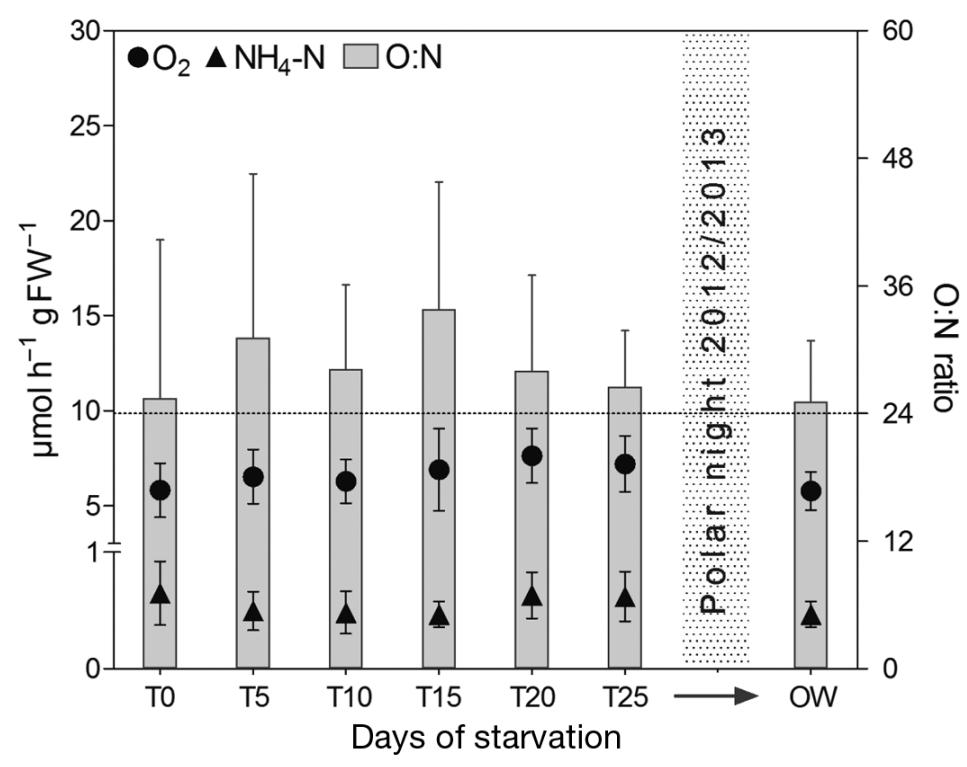

Fig. 1. Oxygen consumption $\left(\mathrm{O}_{2}\right)$, ammonium excretion $\left(\mathrm{NH}_{4}-\mathrm{N}\right)$ and atomic oxygen to nitrogen ratio $(\mathrm{O}: \mathrm{N})$ at $4^{\circ} \mathrm{C}$ of adult Thysanoessa inermis $(\mathrm{n}=8)$ over time of starvation (T0 to T28) and after overwintering (OW; specimens from April 2013). Values are means \pm SD. Dotted line at O:N ratio $=24$ indicates equal use of proteins and lipids (Mayzaud \& Conover 1988). FW: fresh weight

Table 1. Elemental and biochemical composition of female Thysanoessa inermis during starvation (T0 to T28) and after overwintering (OW; specimens from April 2013). Values are means \pm SD. DW: dry weight; $\mathrm{C}$ : body carbon; $\mathrm{N}$ : body nitrogen; $\mathrm{n}$ : number of individuals

\begin{tabular}{|lccccc|}
\hline $\begin{array}{l}\text { Days of } \\
\text { starvation }\end{array}$ & $\mathrm{n}$ & $\begin{array}{c}\text { Dry weight } \\
(\mathrm{mg})\end{array}$ & $\begin{array}{c}\text { Total lipid } \\
(\% \mathrm{DW})\end{array}$ & $\begin{array}{c}\text { Total protein } \\
(\% \mathrm{DW})\end{array}$ & $\begin{array}{c}\mathrm{C}: \mathrm{N} \\
\text { mass ratio }\end{array}$ \\
\hline T0 & 4 & $30.0 \pm 1.6$ & $42.3 \pm 1.1$ & - & - \\
T5 & 5 & $30.9 \pm 4.3$ & - & $34.2 \pm 2.3$ & $6.6 \pm 0.8$ \\
T15 & 4 & $31.9 \pm 3.6$ & $41.2 \pm 7.6$ & - & - \\
T25 & 5 & $25.3 \pm 1.4$ & - & $36.3 \pm 2.8$ & $6.2 \pm 0.6$ \\
T28 & 4 & $20.5 \pm 1.3$ & $27.6 \pm 6.6$ & - & - \\
OW & 4 & $23.7 \pm 2.9$ & $32.2 \pm 2.4$ & - & - \\
\hline
\end{tabular}




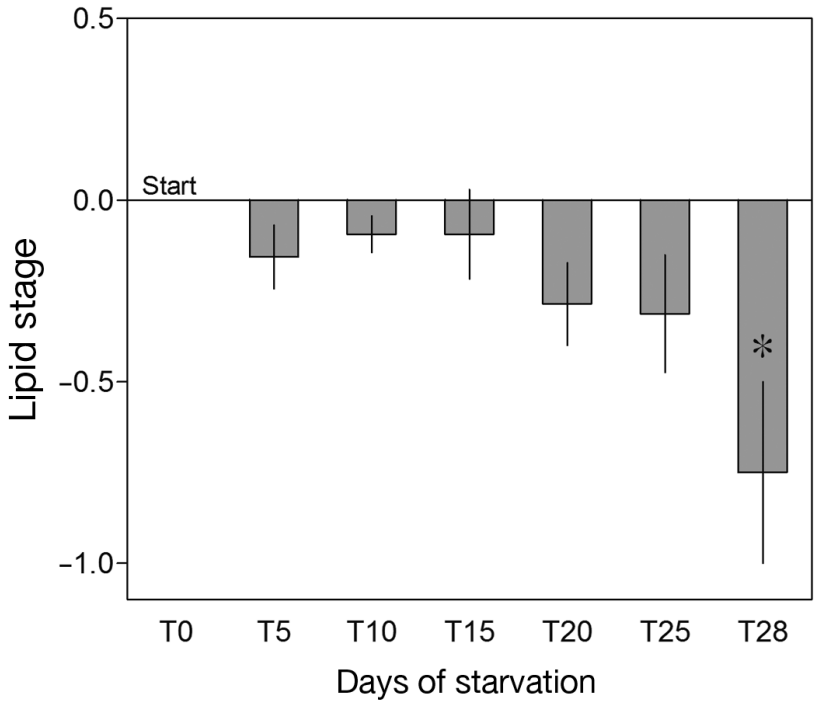

Fig. 2. Mean change in the lipid stages of Thysanoessa inermis ( $\mathrm{n}=8$ to 16 ) over time of starvation (T0 to T28). Error bars represent the standard errors of the means. $*$ : Significant difference to T0 (1-way ANOVA: $\mathrm{p}=0.0136, F_{6,76}=2.9$; post hoc Dunnett test: $\mathrm{p}<0.0001)$

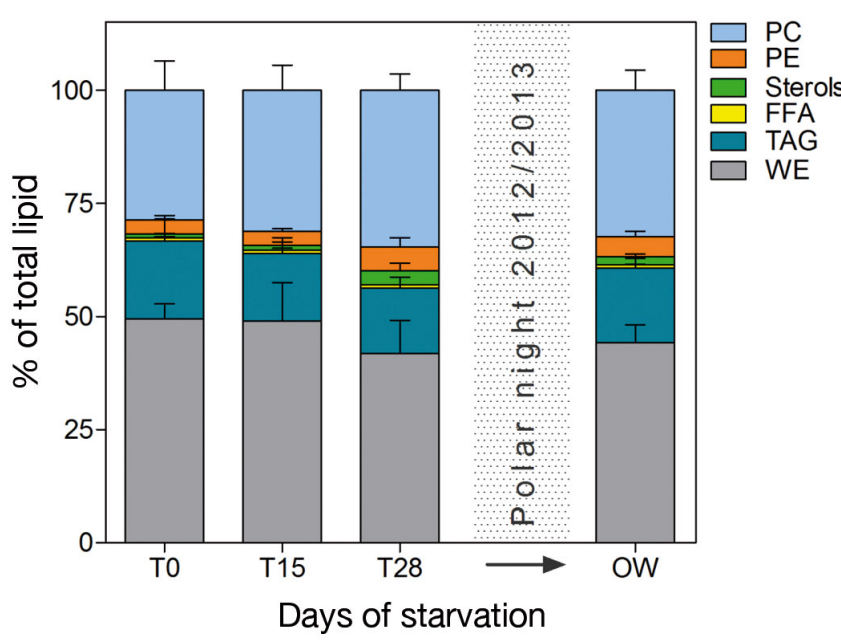

Fig. 3. Lipid class composition of female Thysanoessa inermis $(\mathrm{n}=4)$ over time of starvation (T0 to T28) and after overwintering (OW; specimens from April 2013). Percentages are shown as means $\pm \mathrm{SD}$. WE: wax ester; TAG: triacylglycerol; FFA: free fatty acids; PE: phosphatidylethanolamine; PC: phosphatidylcholine

there was no statistical difference in the fatty acid composition of $T$. inermis during starvation. However, mean values of 16:0 and 16:1(n-7) showed a decreasing trend, whereas those of 18:2(n-6) and 22:6(n-3) increased slightly.
The body weight and composition of OW T. inermis were statistically different compared to unstarved (T0) specimens from August 2012. The dry weight was significantly lower in OW samples ( $24 \mathrm{mg}$; $t$-test: $\mathrm{p}=0.0199, t=3.8, \mathrm{df}=4)$ and the total lipid content was $10 \%$ lower $(\sim 32 \%$ of dry weight; $t$-test: $p=0.003$, $t=7.6, \mathrm{df}=6$; Table 1). Within the lipid classes, sterols were present in higher amounts in OW samples $(\sim 2 \%$ of total lipid; $t$-test: $\mathrm{p}=0.0314, t=2.8, \mathrm{df}=6$; Fig. 3 ). The fatty acid composition of the OW specimens was dominated by the same components as in the August 2012 specimens. Nevertheless, 18:2(n-6) was present in higher amounts ( $t$-test: $\mathrm{p}=0.0023, t=5.1, \mathrm{df}=6)$, whereas 16:1(n-7), 18:1(n-7) and 16:2(n-4) were found in lower amounts $(t$-test: $\mathrm{p}=0.0388, t=2.6, \mathrm{df}=6 ; \mathrm{p}=$ $0.0329, t=2.7, \mathrm{df}=6 ; \mathrm{p}=0.0097, t=3.7, \mathrm{df}=6)$. Furthermore, the 18:4(n-3) atty acid and the long-chain 20:1 and 22:1 fatty acids and alcohols were found in higher amounts in the OW samples, although not in a statistically significant manner due to high standard deviations (Table 2). Among the fatty alcohols, 16:1(n-7) was present in lower amounts in OW samples ( $t$-test: $\mathrm{p}=0.0367, t=2.7, \mathrm{df}=6)$.

In relation to starved individuals of $T$. inermis (T28), OW were not different with regard to dry weight, total lipid, or lipid class composition (Table 1, Fig. 3). Among the fatty acids, the difference was only significant in 16:2(n-4) (traces in OW compared to $\sim 1.1 \%$ at T28; $t$-test: $\mathrm{p}=0.0330, t=2.9, \mathrm{df}=5$ ) and 18:2(n-6) ( 2.4 in OW compared to traces in T28; $t$-test: $\mathrm{p}=0.0156, t=3.6, \mathrm{df}=5$, respectively; Table 2 ).

\section{Potential maximum starvation}

The daily individual energy demand was $7.6 \mathrm{~J}$ ( $0.17 \mathrm{mg}$ lipid) calculated from the mean respiration rate of $6 \mu \mathrm{mol} \mathrm{O} \mathrm{O}_{2} \mathrm{~h}^{-1} \mathrm{~g}^{-1} \mathrm{FW}$ (Fig. 1) and a FW of $\sim 120 \mathrm{mg}$. Assuming an essential minimum lipid content of $5 \%$ (see 'Materials and methods: Calculation of potential maximum starvation'), individual female $T$. inermis contained $\sim 11.2 \mathrm{mg}$ of potentially consumable lipid (37.3\% of $\sim 30 \mathrm{mg}$ dry weight; Table 1$)$, which is equivalent to an energy storage of $\sim 477.7 \mathrm{~J}$ available for overwintering. Accordingly, the lipid reserves alone could cover the energy requirements of an adult female $T$. inermis for $\sim 63 \mathrm{~d}$.

\section{DISCUSSION}

The starvation experiment was performed on adult Thysanoessa inermis at the end of the Arctic summer. 
Table 2. Fatty acid and alcohol compositions (total fatty acids and alcohols, \%) of female Thysanoessa inermis during starvation (T0 to T28) and after overwintering (OW; specimens from April 2013). Values are given as mean percentages $\pm \mathrm{SD}$. Compounds $<1 \%$ are not shown or are marked as traces (tr) as soon as they were present in comparative specimens. SFAs: saturated fatty acids; MUFAs: monounsaturated fatty acids; PUFAs: polyunsaturated fatty acids; n: number of individuals

\begin{tabular}{|c|c|c|c|c|}
\hline \multirow[t]{2}{*}{ Composition } & \multicolumn{3}{|c|}{ Days of starvation } & \multirow{2}{*}{$\begin{array}{c}\text { OW } \\
(\mathrm{n}=4)\end{array}$} \\
\hline & $\begin{array}{c}\text { T0 } \\
(\mathrm{n}=4)\end{array}$ & $\begin{array}{c}\mathrm{T} 15 \\
(\mathrm{n}=4)\end{array}$ & $\begin{array}{c}\mathrm{T} 28 \\
(\mathrm{n}=4)\end{array}$ & \\
\hline \multicolumn{5}{|l|}{ Fatty acids } \\
\hline $14: 0$ & $2.4 \pm 0.1$ & $2.5 \pm 0.5$ & $2.3 \pm 0.3$ & $2.9 \pm 0.6$ \\
\hline $16: 0$ & $21.7 \pm 0.9$ & $23.0 \pm 1.0$ & $20.8 \pm 1.5$ & $20.8 \pm 1.0$ \\
\hline $18: 0$ & $1.8 \pm 0.4$ & $2.0 \pm 0.1$ & $2.0 \pm 0.2$ & $1.6 \pm 0.4$ \\
\hline$\Sigma$ SFAs & $25.9 \pm 1.2$ & $27.5 \pm 1.4$ & $25.0 \pm 1.9$ & $25.3 \pm 0.9$ \\
\hline $16: 1(n-7)$ & $12.7 \pm 1.5$ & $11.6 \pm 4.1$ & $11.2 \pm 1.4$ & $6.9 \pm 4.1$ \\
\hline $18: 1(n-9)$ & $22.3 \pm 0.7$ & $22.7 \pm 1.1$ & $22.0 \pm 2.3$ & $22.3 \pm 3.4$ \\
\hline $18: 1(n-7)$ & $12.2 \pm 1.0$ & $10.1 \pm 0.8$ & $11.2 \pm 1.5$ & $9.3 \pm 1.8$ \\
\hline $20: 1(n-9)$ & $\operatorname{tr}$ & $\operatorname{tr}$ & $\operatorname{tr}$ & $2.9 \pm 3.9$ \\
\hline $22: 1(n-11)$ & $\operatorname{tr}$ & $\operatorname{tr}$ & $\operatorname{tr}$ & $1.3 \pm 2.3$ \\
\hline$\Sigma$ MUFAs & $49.0 \pm 1.6$ & $46.1 \pm 3.8$ & $46.2 \pm 3.6$ & $43.6 \pm 4.1$ \\
\hline $16: 2(n-4)$ & $1.2 \pm 0.2$ & $1.0 \pm 0.3$ & $1.1 \pm 0.1$ & $\operatorname{tr}$ \\
\hline $18: 2(n-6)$ & $\operatorname{tr}$ & $1.1 \pm 0.6$ & $1.1 \pm 0.1$ & $2.4 \pm 0.6$ \\
\hline $18: 4(n-3)$ & $2.2 \pm 0.1$ & $3.1 \pm 1.6$ & $2.0 \pm 0.3$ & $4.8 \pm 2.6$ \\
\hline $20: 5(n-3)$ & $15.3 \pm 1.0$ & $15.3 \pm 1.3$ & $15.6 \pm 0.7$ & $14.4 \pm 0.6$ \\
\hline $22: 6(n-3)$ & $4.5 \pm 1.4$ & $4.6 \pm 1.3$ & $7.3 \pm 1.2$ & $6.9 \pm 1.3$ \\
\hline$\Sigma$ PUFAs & $25.1 \pm 1.1$ & $26.3 \pm 2.4$ & $28.8 \pm 1.9$ & $31.1 \pm 3.7$ \\
\hline \multicolumn{5}{|l|}{ Fatty alcohols } \\
\hline $14: 0^{\prime}$ & $24.7 \pm 2.1$ & $25.7 \pm 4.6$ & $24.8 \pm 0.5$ & $29.9 \pm 4.1$ \\
\hline $16: 0$ & $57.6 \pm 2.4$ & $58.2 \pm 1.5$ & $57.5 \pm 1.6$ & $51.8 \pm 10.7$ \\
\hline $16: 1(n-7)^{a}$ & $16.2 \pm 2.2$ & $15.6 \pm 4.8$ & $17.8 \pm 1.6$ & $9.6 \pm 4.4$ \\
\hline $20: 1(n-9 / n-7)$ & $\operatorname{tr}$ & $\operatorname{tr}$ & - & $4.0 \pm 7.0$ \\
\hline $22: 1(n-11 / n-9)$ & $\operatorname{tr}$ & - & - & $4.7 \pm 8.8$ \\
\hline
\end{tabular}

when they were sexually regressed, only female specimens were used for lipid analyses to avoid sex-specific influences (e.g. Clarke 1980).

All of the specimens sampled for the experiment in August 2012 were sexually inactive. In $\sim 7 \%$ of the specimens, sexual regression had progressed to such an extent that clear sex determination was not possible. In euphausiids, sexual regression is a common functional response to longer periods of food scarcity. It is an adaptation to reduce metabolic costs when species are unable to cover reproductive needs sufficiently, e.g. during overwintering, as found in the Antarctic Euphausia superba (Kawaguchi et al. 2007), the boreal Meganyctiphanes norvegica (Cuzin-Roudy \& Buchholz 1999) and also in T. inermis from the Barents Sea (Dalpadado \& Ikeda 1989). Hence, our study confirmed that $T$. inermis may take advantage of this adaptation to save energy, especially over winter. As the regression had already started in late summer, it was probably triggered by the already limited food supply (Dalpadado \& Ikeda 1989), indicated by the low chlorophyll a concentration in the first week of August $2012\left(<0.5 \mu \mathrm{g} \mathrm{l}^{-1}\right.$; see above).

In addition to sexual regression, body shrinkage is a further common morphological adaptation induced by inadequate nutrition (e.g. Meyer 2012 and references

During this time, phytoplankton (determined as chlorophyll a concentration) was already low $(<0.5 \mu \mathrm{g}$ $\mathrm{I}^{-1}$; ref. COSYNA data web portal 'Underwaternode Spitsbergen' operated by AWI and the HelmholtzZentrum Geesthacht Zentrum für Material- und

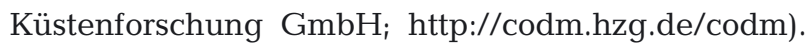
This is in contrast to spring bloom situations, in which the concentration can reach $13 \mu \mathrm{g} \mathrm{l}^{-1}$ (Hegseth \& Tverberg 2013). This was also reflected in the nutritional condition of $T$. inermis at the start of the experiment. Generally, during times of high food supply, the colour of the midgut gland depends on the specific source of nutrition and can vary between colourless, green and red. Most of the specimens had an empty stomach and a colourless hepatopancreas, indicating only occasional or even no feeding before catch.

Nevertheless, high lipid contents $(\sim 42 \%)$ in the specimens revealed that $T$. inermis was well prepared for the upcoming winter. Even though Huenerlage et al. (2014) found no statistical differences in the lipid composition of adult male and female $T$. inermis therein) that reduces the loss of metabolic energy during times of food scarcity. Shrinkage was first described for experiments on the overwintering mechanisms of the Antarctic E. superba (Ikeda \& Dixon 1982), where moulting continued resulting in negative growth. In our experiment, the intermoult period remained stable and was defined to be $\sim 11 \mathrm{~d}$ at $4^{\circ} \mathrm{C}$, corresponding to values in previous studies on T. inermis at $5^{\circ} \mathrm{C}$ (Dalpadado \& Ikeda 1989). However, $T$. inermis sampled in the first week of April 2013, after overwintering in the field, showed the same mean body length as the specimens sampled in August 2012, pointing to stagnation in the growth of this species (e.g. Hopkins et al. 1984). As in E. superba, T. inermis from the Barents Sea showed negative growth over winter, i.e. from August to February of the following year (Dalpadado \& Skjoldal 1996). Hence, as positive growth probably re-started in February, the specimens sampled in April 2013 may have already compensated for body shrinkage and attained the same size as before the winter. 
One of the most pronounced responses to starvation in euphausiids and other crustacean zooplankton (e.g. copepods) is a significant decrease in respiration rate (e.g. Quetin \& Ross 1991, Auel et al. 2003, Meyer 2012). Euphausiids from other latitudes, such as the adult Antarctic E. superba and the southern Atlantic upwelling species Euphausia hanseni, downregulated their respiration rates by up to $70 \%$ during winter and/or during food absence, respectively (e.g. Meyer 2012 and references therein, Huenerlage \& Buchholz 2013). In T. inermis, however, the respiration rate did not change within the first 28 starvation days and was the same in the overwintered specimens sampled in April 2013 (this study) and specimens sampled in mid-summer (Huenerlage et al. unpubl. data). It is an exception, from the respiration point of view, that metabolic costs remained stable in T. inermis. It neither reduced its overall metabolism during the starvation experiment nor was it found to have done so right after winter. Instead, the mean respiration rate $\left(\sim 6 \mu \mathrm{mol} \mathrm{O} \mathrm{O}_{2} \mathrm{~h}^{-1} \mathrm{~g}^{-1} \mathrm{FW}\right)$ remained comparable to that of unstarved euphausiids investigated at in situ temperatures from other latitudes (e.g. Ikeda \& Mitchell 1982, Saborowski et al. 2002, Auerswald et al. 2009, Huenerlage \& Buchholz 2013).

Excretion rates did not change either. Both, specimens subjected to the starvation experiment and krill that had overwintered had excretion rates of $\sim 0.55 \mu \mathrm{mol} \mathrm{NH}_{4}-\mathrm{N} \mathrm{h}^{-1} \mathrm{gFW}^{-1}$. Excretion is closely related to the food ingested (e.g. Saborowski et al. 2002). Hence, high phytoplankton concentrations correlate with high ammonium excretion rates, whereas the absence of food leads to a strong decrease in excretion within days (e.g. Huenerlage \& Buchholz 2013). In August 2012, T. inermis had already been exposed to food depletion before catch (see above). Accordingly, the excretion rate was most likely already at its minimum at the start of the experiment, and there was therefore no further change.

In all $T$. inermis sampled, the atomic O:N ratio pointed to a lipid-dominated metabolism (Mayzaud $\&$ Conover 1988). The mean O:N ratio stayed above 24, both in the specimens from August 2012, over the time of starvation and after in situ overwintering in April 2013. Concomitantly, lipid analyses showed a clear decrease in total lipid over the time of starvation, whereas the percentage of protein content remained stable. In euphausiids, proteins are reported to play a minor role in the allocation of energy and are known to be only metabolized after the depletion of lipid stores (Torres et al. 1994, Auerswald et al. 2009). Hence, our results showed that, under food depletion, the metabolic energy demand of $T$. inermis is mainly covered by the catabolism of storage lipids.

In most krill species, lipids are stored as triacylglycerols (Saether et al. 1986). In contrast, T. inermis primarily uses wax esters ( $\sim 50 \%$ of total lipid in the specimens of this study) which are specifically biosynthesized during the exploitation of the spring and (early) summer phytoplankton blooms (FalkPetersen et al. 2000). Compared to triacylglycerols, wax esters have a higher calorific content and are considered as more persistent long-term energy deposits (Lee et al. 2006). They are most commonly reported in polar copepods (Scott et al. 2000). In euphausiids, this lipid class is only present in some species, e.g. in the Antarctic Euphausia crystallorophias and Thysanoessa macrura and in the North Atlantic T. inermis and its congeners T. raschii and T. longicaudata (e.g. Falk-Petersen et al. 2000, Huenerlage et al. 2014).

T. inermis uses both wax esters and triacylglycerols for energy provision (Saether et al. 1986). However, despite the significant decrease of total lipid over the time of starvation and after overwintering, we did not find a significant change in any of the single lipid classes. Rather, wax esters and triacylglycerols showed a decreasing trend, whereas the proportion of polar lipids increased. Additionally, although no storage lipid, the relative proportion of sterols was significantly increased, indicating a simultaneous catabolism of both the wax esters and the triacylglycerols. The total share of the polar lipids and the sterols did not change. This would explain the relative increase of these lipid classes in proportion to total lipids.

Based on the wax ester-dominated lipid metabolism of $T$. inermis, we calculated a daily energy demand of $\sim 7.6 \mathrm{~J} \mathrm{~d}^{-1}$. Taking into account the mean metabolic costs of an individual and the critical lipid limit of $5 \%$ essential for survival (Saether et al. 1986, Hagen et al. 2001), we assessed the potential survival time of adult $T$. inermis at $63 \mathrm{~d}$. Hence, assuming a minimum starvation period of $116 \mathrm{~d}$ during polar winter (Hop et al. 2002), i.e. irrespective of the already variable phytoplankton concentration in late summer (Eilertsen et al. 1989, Hop et al. 2002), the lipid store alone would not be sufficient to cover the metabolic energy requirements of this species.

As a consequence, T. inermis must (at least occasionally) switch to alternative food sources to survive the winter. This assumption is further confirmed by the high lipid contents found in the overwintered specimens that were sampled in prebloom conditions during the first week of April 2013 
(chlorophyll a concentration $<0.06 \mu \mathrm{g} \mathrm{l}^{-1}$; source: COSYNA). The total lipid of the overwintered specimens was even slightly higher than that of the starved specimens at the end of the experiment in August 2012.

The analysis of fatty acid markers is frequently used to determine or confirm trophic relationships (Dalsgaard 2003). Compared to traditional stomach analyses, which only reflect recent feeding, the determination of fatty acids is especially used to detect long-term nutritional changes (Dalsgaard 2003 and references therein). In our study, fatty acids did not change over the time of starvation but indicated differences between the 2 seasons, i.e. at the start of the experiment in August 2012 and after overwintering in April 2013. The analysis of fatty acids was therefore useful to identify the potential prey composition for krill during winter.

The probable change to different food sources was mainly indicated by the significant decrease in diatom markers (16:1(n-7) and 18:1(n-7), e.g. Stübing \& Hagen 2003) and the simultaneous increase in Calanus markers, i.e. long-chain 20:1(n-9/n-7) and 22:1(n-11/n-9) fatty acids and alcohols (e.g. Dalsgaard 2003). However, with regard to the Calanus markers, high standard deviations indicated strong differences between the individuals investigated, indicating unpredictable food sources and opportunistic feeding. Nevertheless, this finding serves as evidence of increased carnivory the winter. Calanoid copepods from the Arctic (i.e. Calanus finmarchicus, C. hyperboreus and C. glacialis) are characterized by high lipid contents depending on species, size and developmental stage (e.g. Scott et al. 2000, Auel et al. 2003, Falk-Petersen et al. 2009). Their lipid store can even exceed $70 \%$ of their dry weight (e.g. FalkPetersen et al. 2009). Accordingly, T. inermis could obtain enough energy from occasional feeding on these Arctic copepods. For example, the total digestion of 1 calanoid copepod C. hyperboreus ( 55 J ind. ${ }^{-1}$; Auel et al. 2003) would supply enough energy to cover the energetic requirements of $T$. inermis for $\sim 7 \mathrm{~d}$. Additionally, T. inermis may follow the behaviour of its congener $T$. raschii and switch to temporary detritus and benthic feeding (Sargent \& FalkPetersen 1981).

In summary, we suggest the overwintering pattern of $T$. inermis as an effective combination of 4 different physiological characteristics: (1) sexual regression; (2) body shrinkage, i.e. growth stagnation; (3) use of internal body stores (mainly lipid); and (4) occasional predation on calanoid copepods and potentially benthic feeding.
In crustaceans, there are at least 3 strategies to survive periods of food scarcity, i.e. overwintering. They are defined through different energetic adaptations (Torres et al. 1994, Hagen 1999). According to Torres et al. (1994), euphausiids are classified to exhibit a 'Type 2' strategy. This strategy is, in addition to the use of internal body reserves and opportunistic feeding behaviour, basically characterized by a pronounced reduction in metabolic rates.

Metabolic reduction, as a result of food absence, was found in krill of different climatic zones, e.g. in North Atlantic $M$. norvegica, the subtropical $E$. hanseni and the Antarctic E. superba (e.g. Quetin \& Ross 1991, Saborowski et al. 2002, Meyer 2012, Huenerlage \& Buchholz 2013). During overwintering in E. superba, $>71 \%$ of the energetic costs are covered solely by lowering metabolic rates (Quetin \& Ross 1991). However, T. inermis did not reduce its overall metabolism at all during the starvation experiment (this study), which was the same as that measured in spring and summer (Huenerlage et al. pers. obs.).

Furthermore, the mode of energy storage distinguishes this species from the other investigated krill species. Unlike M. norvegica and E. superba (both exhibiting triacylglycerols as an energy depot), $T$. inermis shows higher amounts of total lipids and is able to biosynthesize energy-rich wax esters de novo as its major energy storage (Falk-Petersen et al. 2000). This difference is even more pronounced compared to the subtropical upwelling species E. hanseni, which stores almost no lipids and is therefore not adapted to longer periods of starvation (Huenerlage \& Buchholz 2013). In the highly productive upwelling system of the northern Benguela Current, this species is consistently surrounded by a 'basic food supply', additionally supplemented by frequent short-term phytoplankton blooms, i.e. upwelling events (T. Werner \& F. Buchholz unpubl. data). Accordingly, E. hanseni is rarely exposed to extreme food limitation and therefore is not at all adapted to storing lipids. In contrast, its true polar Antarctic congener, E. superba, is well adapted to seasonally changing food availability, i.e. to long periods of food absence during austral winter (Meyer 2012 and references therein, Schmidt et al. 2014). Nevertheless, during austral summer, E. superba experiences a long period of food abundance, as the Southern Ocean is believed to be one of the most productive areas, albeit with a patchy distribution of food sources (Smith et al. 1998, Schmidt et al. 2014). However, E. superba's pronounced metabolic compensation when faced with food absence most likely developed helping to survive the annual overwintering period. 
In comparison, the arcto-boreal $T$. inermis experiences successive periods of low phytoplankton concentrations in addition to the long period of food deprivation during polar winter. In the Kongsfjord ecosystem, summer primary production also experiences strong variations; these are partly determined by the decrease in the euphotic zone attributed to the seasonal increase in turbidity due to river runoff and glacial outflow (Eilertsen et al. 1989, Hop et al. 2002). Hence, in the high-Arctic Kongsfjord, the only predictable phytoplankton production occurs in late spring (Hop et al. 2002), when T. inermis accumulates its energy-rich wax ester storage lipids (FalkPetersen et al. 2000).

According to Torres et al. (1994), wax ester storage is the major characteristic of the 'Type 1' survival strategy and is generally exhibited by diapausing copepods. However, T. inermis does not diapause, i.e. it remains active during winter and switches to alternative food sources. In turn, this is the common pattern in crustaceans exhibiting the 'Type 3' survival strategy, e.g., decapods, mysids and gammarid amphipods (Torres et al. 1994, Hagen 1999). In summary, $T$. inermis shows a different overwintering strategy (i.e. metabolic response to starvation) compared to krill species from other regions. The survival pattern of $T$. inermis may be categorized as intermediate between the 'Type 1' (linked by its high wax ester content) and the 'Type 3' strategy (linked by its constant metabolic activity and opportunistic feeding behaviour).

\section{CONCLUSION}

The arcto-boreal $T$. inermis appears to cope with both successive and long periods of food limitation determined by strong seasonality. This is in contrast to the subtropical upwelling krill species E. hanseni, which follows a 'hand-to-mouth' existence with only a limited capability to survive long-term food deprivation due to very low lipid reserves (Huenerlage \& Buchholz 2013).

In most respects, the survival strategy of $T$. inermis was found to be similar to that of the Antarctic E. superba and the northern krill Meganyctiphanes norvegica (i.e. body shrinkage, sexual regression, use of internal energy storage and opportunistic feeding). However, differences were found in terms of the energy storage pattern (long-term wax ester storage in $T$. inermis vs. short-term triacylglycerols) and the outstanding characteristic of $T$. inermis not to reduce its overall metabolism.
Accordingly, our study highlights the diversity in physiological responses to starvation of different krill species adapted to their different habitats. In future experiments, investigations on the species' metabolic and digestive enzyme activities and kinetics may be useful to increase our knowledge of the physiological performance of $T$. inermis during winter, i.e. under starvation conditions (e.g. Kreibich et al. 2008, Freese et al. 2012).

Acknowledgements. We thank the captains of the Kings Bay AS workboat MS 'Teisten'. We are very grateful for the professional support by the AWIPEV station leaders and (logistic) engineers, Ny-Ålesund, Spitsbergen. We thank the Department of Marine Zoology headed by Prof. Dr. Wilhelm Hagen (BreMarE-Centre for Research \& Education, University of Bremen, Germany) for allowing us to use their facilities for lipid extraction. We are grateful to Dieter Janssen for his help in lipid class analyses at the AWI laboratories, Bremerhaven. We thank Ruth Alheit for the final language edit as a native speaker. The data from the COSYNA data web portal were originally provided by Prof. Dr. Philipp Fischer (AWI), Dr. Gisbert Breitbach (HZG), Prof. Dr. Burkard Baschek (HZG) and Dr. Friedhelm Schroeder (HZG). This work was supported by the French-German AWIPEV project KOP 124, RIS ID 3451.

\section{LITERATURE CITED}

Atkinson A, Meyer B, Bathmann U, Stübing D, Hagen W, Schmidt K (2002) Feeding and energy budget of Antarctic krill Euphausia superba at the onset of winter. II. Juveniles and adults. Limnol Oceanogr 47:953-966

- Auel H, Klages M, Werner I (2003) Respiration and lipid content of the Arctic copepod Calanus hyperboreus overwintering $1 \mathrm{~m}$ above the seafloor at $2300 \mathrm{~m}$ water depth in the Fram Strait. Mar Biol 143:275-282

> Auerswald L, Pape C, Stübing D, Lopata A, Meyer B (2009) Effect of short-term starvation of adult Antarctic krill, Euphausia superba, at the onset of summer. J Exp Mar Biol Ecol 381:47-56

> Buchholz F (1982) Drach's molt staging system adapted for euphausiids. Mar Biol 66:301-305

> Buchholz F (2003) Experiments on the physiology of southern and northern krill, Euphausia superba and Meganyctiphanes norvegica, with emphasis on moult and growth $-\mathrm{a}$ review. Mar Freshwat Behav Physiol 36: 229-247

Buchholz F, Buchholz C, Weslawski JM (2010) Ten years after: krill as indicator of changes in the macro-zooplankton communities of two Arctic fjords. Polar Biol 33:101-113

Clarke A (1980) The biochemical composition of krill, Euphausia superba Dana, from South Georgia. J Exp Mar Biol Ecol 43:221-236

Cuzin-Roudy J, Buchholz F (1999) Ovarian development and spawning in relation to the moult cycle in northern krill, Meganyctiphanes norvegica (Crustacea: Euphausiacea), along a climatic gradient. Mar Biol 133:267-281

Dalpadado P, Ikeda T (1989) Some observations on moulting, growth and maturation of krill (Thysanoessa inermis) from the Barents Sea. J Plankton Res 11:133-139

> Dalpadado P, Mowbray F (2013) Comparative analysis of 
feeding ecology of capelin from two shelf ecosystems, off Newfoundland and in the Barents Sea. Prog Oceanogr 114:97-105

> Dalpadado P, Skjoldal HR (1996) Abundance, maturity and growth of the krill species Thysanoessa inermis and $T$. longicaudata in the Barents Sea. Mar Ecol Prog Ser 144:175-183

Dalsgaard J (2003) Fatty acid trophic markers in the pelagic marine environment. In: Southward AJ, Tyler PA, Young CM, Fuiman LA (eds) Advances in marine biology, Vol 46. Academic Press, New York, NY, p 225-340

Eilertsen HC, Taasen JP, Weslawski JM (1989) Phytoplankton studies in the fjords of West Spitzbergen: physical environment and production in spring and summer. J Plankton Res 11:1245-1260

> Falk-Petersen S, Hagen W, Kattner G, Clarke A, Sargent J (2000) Lipids, trophic relationships, and biodiversity in Arctic and Antarctic krill. Can J Fish Aquat Sci 57: 178-191

Falk-Petersen S, Mayzaud P, Kattner G, Sargent JR (2009) Lipids and life strategy of Arctic Calanus. Mar Biol Res 5:18-39

> Freese D, Kreibich T, Niehoff B (2012) Characteristics of digestive enzymes of calanoid copepod species from different latitudes in relation to temperature, $\mathrm{pH}$ and food. Comp Biochem Physiol B 162:66-72

> Graeve M, Janssen D (2009) Improved separation and quantification of neutral and polar lipid classes by HPLCELSD using a monolithic silica phase: application to exceptional marine lipids. J Chromatogr B 877:1815-1819

Hagen W (1999) Reproductive strategies and energetic adaptations of polar zooplankton. Invertebr Reprod Dev 36:25-34

Hagen W (2000) Lipids. In: Harris R, Wiebe P, Lenz J, Skjoldal H, Huntley M (eds) ICES zooplankton methodology manual. Academic Press, London, p 113-119

- Hagen W, Kattner G, Terbrüggen A, van Vleet ES (2001) Lipid metabolism of the Antarctic krill Euphausia superba and its ecological implications. Mar Biol 139:95-104

> Hegseth EN, Tverberg V (2013) Effect of Atlantic water inflow on timing of the phytoplankton spring bloom in a high Arctic fjord (Kongsfjorden, Svalbard). J Mar Syst 113-114:94-105

Hop H, Pearson T, Hegseth EN, Kovacs KM and others (2002) The marine ecosystem of Kongsfjorden, Svalbard. Polar Res 21:167-208

> Hopkins CC, Tande KS, Grønvik S, Sargent JR (1984) Ecological investigations of the zooplankton community of Balsfjorden, northern Norway: an analysis of growth and overwintering tactics in relation to niche and environment in Metridia longa (Lubbock), Calanus finmarchicus (Gunnerus), Thysanoessa inermis (Krøyer) and T. raschi (M. Sars). J Exp Mar Biol Ecol 82:77-99

> Huenerlage K, Buchholz F (2013) Krill of the northern Benguela Current and the Angola-Benguela frontal zone compared: physiological performance and short-term starvation in Euphausia hanseni. J Plankton Res 35: 337-351

> Huenerlage K, Graeve M, Buchholz F (2014) Lipid composition and trophic relationships of krill species in a high Arctic fjord. Polar Biol, doi:10.1007/s00300-014-1607-6

Ikeda T, Dixon P (1982) Body shrinkage as a possible overwintering mechanism of the Antarctic krill, Euphausia superba Dana. J Exp Mar Biol Ecol 62:143-151

Ikeda T, Mitchell AW (1982) Oxygen uptake, ammonia excretion and phosphate excretion by krill and other Antarctic zooplankton in relation to their body size and chemical composition. Mar Biol 71:283-298

Ikeda T, Torres JJ, Hernández-León S, Geiger SP (2000) Metabolism. In: Harris R, Wiebe P, Lenz J, Skjoldal H, Huntley $M$ (eds) ICES zooplankton methodology manual. Academic Press, London, p 455-458

Kattner G, Fricke HSG (1986) Simple gas-liquid chromatographic method for the simultaneous determination of fatty acids and alcohols in wax esters of marine organisms. J Chromatogr A 361:263-268

Kawaguchi S, Yoshida T, Finley L, Cramp P, Nicol S (2007) The krill maturity cycle: a conceptual model of the seasonal cycle in Antarctic krill. Polar Biol 30:689-698

Kreibich T, Saborowski R, Hagen W, Niehoff B (2008) Shortterm variation of nutritive and metabolic parameters in Temora longicornis females (Crustacea, Copepoda) as a response to diet shift and starvation. Helgol Mar Res 62:241-249

$>$ Lee RF, Hagen W, Kattner G (2006) Lipid storage in marine zooplankton. Mar Ecol Prog Ser 307:273-306

Lydersen C (2014) Status and biology of ringed seals (Phoca hispida) in Svalbard. NAMMCO Sci Publ 1:46-62

- Mayzaud P, Conover RJ (1988) O:N atomic ratio as a tool to describe zooplankton metabolism. Mar Ecol Prog Ser 45: 289-302

> Meyer B (2012) The overwintering of Antarctic krill, Euphausia superba, from an ecophysiological perspective. Polar Biol 35:15-37

Quetin LB, Ross RM (1991) Behavioral and physiological characteristics of the Antarctic krill, Euphausia superba. Am Zool 31:49-63

> Saborowski R, Bröhl S, Tarling G, Buchholz F (2002) Metabolic properties of northern krill, Meganyctiphanes norvegica, from different climatic zones. I. Respiration and excretion. Mar Biol 140:547-556

Saether O, Ellingsen TE, Mohr V (1986) Lipids of North Atlantic krill. J Lipid Res 27:274-285

Sargent JR, Falk-Petersen S (1981) Ecological investigations on the zooplankton community in Balsfjorden, northern Norway: lipids and fatty acids in Meganyctiphanes norvegica, Thysanoessa raschi and $T$. inermis during midwinter. Mar Biol 62:131-137

Schmidt K, Atkinson A, Pond DW, Ireland LC (2014) Feeding and overwintering of Antarctic krill across its major habitats: the role of sea ice cover, water depth, and phytoplankton abundance. Limnol Oceanogr 59:17-36

Scott CL, Kwasniewski S, Falk-Petersen S, Sargent JR (2000) Lipids and life strategies of Calanus finmarchicus, Calanus glacialis and Calanus hyperboreus in late autumn, Kongsfjorden, Svalbard. Polar Biol 23:510-516

Smith RC, Baker KS, Byers ML, Stammerjohn SE (1998) Primary productivity of the Palmer long term ecological research area and the Southern Ocean. J Mar Syst 17: 245-259

Solorzano L (1969) Determination of ammonia in natural waters by the phenolhypochlorite method. Limnol Oceanogr 14:799-801

Stübing D, Hagen W (2003) Fatty acid biomarker ratiossuitable trophic indicators in Antarctic euphausiids? Polar Biol 26:774-782

Tarling GA, Shreeve RS, Hirst AG, Atkinson A and others (2006) Natural growth rates in Antarctic krill (Euphausia superba). I. Improving methodology and predicting intermolt period. Limnol Oceanogr 51:959-972

Torres JJ, Donnelly J, Hopkins TL, Lancraft TM, Aarset AV, Ainley DG (1994) Proximate composition and overwintering strategies of Antarctic micronektonic Crustacea. Mar Ecol Prog Ser 113:221-232 